\title{
Spatial Biculturalism for schools in Aotearoa New Zealand
}

\author{
ARTICLE TYPE: COMMENTARY
}

\section{Georgina Stewart and Leon Benade}

georgina.stewart@aut.ac.nz

Auckland University of Technology, Auckland, Aotearoa New Zealand

Te Tiriti o Waitangi/the Treaty of Waitangi is considered the founding national document of Aotearoa New Zealand, and underpins a bicultural relationship between iwi Māori and European settlers of mainly British origin. As a defining feature of national history and politics, this bicultural relationship means that any discussion of Māori education is inherently political. The specific nature of this bicultural relationship reflects greater socio-political bilateralism compared with more restricted versions of 'biculturalism' found in similar settler countries (Australia, Canada, USA). Supporting social justice for Māori in education, biculturalism has been part of national education policy since 1984, and a full Māori-medium school curriculum has existed since 2010. Yet the potential of bicultural education remains unrealised. Current school building policy in Aotearoa New Zealand presents opportunities to work towards realising the goals of educational biculturalism, as part of Māori political aspirations for Māori futures more generally. These are matters of intense interest and significance for education researchers.

Current Ministry of Education policy calls for the construction of Quality Learning Spaces (QLS), representing yet another shift in nomenclature (beginning with Modern Learning Environments, then shifting to Innovative Learning Environments). Despite shifting nomenclature, the essence of the policy favours provision of Flexible Learning Spaces (FLS), that is, school buildings featuring 'loose fit' interior spaces. Beyond what may seem like mere mundane matters of property infrastructure, this policy for modernising New Zealand's ageing school property portfolio entails significant changes for all members of the school community. The nature, extent and consequences of these changes to school life have increasingly begun to feature in recent national education research discourse-yet, with few exceptions, discussions have been limited in focus to building performance or human activity within buildings, with minimal consideration to wider socio-material and political implications. 
The only existing policy document on Māori FLS takes a homogenising 'equity' lens, focusing on 'the impact of physical design on Māori and Pasifika student outcomes' (Ministry of Education, 2016). The equity approach does not account for Māori-centred perspectives and desires for school reform. Indeed, equity thinking originates in and easily succumbs to underlying (covert) policy goals of assimilation. While not framed in the language of learning environments and current policy, an example of Māori-centred, Kaupapa Māori research that connects Māori with school buildings is a study on the impact of school marae on Māori students (Lee, Pihama, \& Smith, 2012).

The idea of bicultural education as a form of social justice can be combined with the concept of spatial justice to give rise to the novel concept of 'spatial biculturalism' in education. FLS offer an opportunity to enable a shift in educational practice towards spatial biculturalism that deserves to be taken into account in school building projects. FLS can support the embedding of place-based cultural narratives, culturally responsive pedagogy, and bicultural curriculum, understood widely to include 'all' school experiences, into the structures and spatial relationships of the built environment within schools.

The concept of 'spatial biculturalism' combines the ideals of biculturalism in education, with its inherent social justice foundation, and the theory of spatial justice, articulated by Edwin Soja (2010) as arising from "the omnipresence of geographically uneven development and its associated spatial inequalities" (p. 71). Soja highlighted a particular ontological distortion resulting from an over-emphasis on the social and historical aspects of human life, at the expense of the spatial. Soja called for an ontology of spatiality that did not treat 'space' as dead, inert or ethically neutral. This perspective means our lives as spatial beings are no less important than our lives as historical beings. People are essentially spatial beings, embedded in their geographies as much as in their histories.

Soja's theory of spatial justice rests on three ontological qualities of human existence: the social, the historical and the spatial. Thus, all knowledge production ought to take this triad into account. Soja's theory of spatial justice also relies on the insight that space is socially produced (Lefebvre, 1991), a notion that challenges views of space that are either empirical/mathematical or mental. Lefebvre's insight was to develop an ontology of space, which for Soja means that particular geographies have positive or negative consequences. Space can be liberating, emancipatory and creative, but can also disempower and constrain. As 
socially produced, space is thus amenable to human agency, meaning "our geographies [are] the targets for social and political action" (Soja, 2010, p. 104). In these terms, school spaces comprise the geographies of teacher practice.

The dominant ways that Māori culture has been interpreted into 'bicultural' education policy in this country can be critiqued as succumbing to truncated accounts of Māori ontology. The cultural significance of working in Māori teaching spaces for Māori students, their teachers and whānau was demonstrated in the school marae research, noted above (Lee, Pihama, \& Smith, 2012). Soja linked spatial justice to the concept of the 'right to the city', which highlights the right of all the inhabitants of the city to share in an equitable distribution of urban resources. In schooling contexts, analogous questions can be asked about whether Māori communities are enjoying a 'fair share' of the considerable capital resources committed by past and present governments to the construction and remodelling of school property, and whether the experience of Māori communities of the entire process is a fulfilling one. Do FLS honour the cultural particularities of place? Do they contribute meaningfully to enhance and acknowledge the communities they serve, in ways that redress past neglect of these communities and their cultural histories?

How do kura Māori use FLS to support tikanga Māori, and how can FLS in kura Māori honour the local environment and indigenous knowledge within education practice? How might the experiences of kura Māori inform learning environment theory and practice more generally? To address questions such as these in educational research will address the lack of existing Māori FLS research, and the wider gap in international FLS research on the triadic nexus of space, learning, and culture.

\section{References}

Lee, J. B. J., Pihama, L., \& Smith, L. (2012). Marae ā-kura: Teaching, learning and living as Māori: summary report. Retrieved from http://www.tlri.org.nz/sites/default/files/projects/9283_summaryreport.pdf

Lefebvre, H. (1991). The production of space. Malden MA: Blackwell.

Ministry of Education. (2016). Māui whakakau, kura whakakau: the impact of physical design on Māori and Pasifika student outcomes. Retrieved from http://www.education.govt.nz/assets/Documents/Primary-Secondary/Property/Schoolproperty-design/Flexible-learning-spaces/FLS-Maui-whakakau-kura-whakakau.pdf 
Soja, E. W. (2010). Seeking spatial justice. Minneapolis MN \& London UK: University of Minnesota Press. 